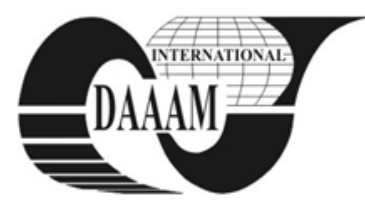

Annals of DAAAM for 2011 \& Proceedings of the 22nd International DAAAM Symposium, Volume 22, No. 1, ISSN 1726-9679 ISBN 978-3-901509-83-4, Editor B. Katalinic, Published by DAAAM International, Vienna, Austria, EU, 2011 Make Harmony between Technology and Nature, and Your Mind will Fly Free as a Bird Annals \& Proceedings of DAAAM International 2011

\title{
SMALL SMART HOUSE
}

\author{
MISAK, S[tanislav]; PROKOP, L[ukas] \& KACOR, P[etr]
}

\begin{abstract}
This paper presents the key results of creating an energy concept for a family house island system, a so-called Small Smart House built in the premises of the VŠB - Technical University of Ostrava, in the Czech Republic. Basic conditions of power concept and simplified block diagram were introduced in this text too.
\end{abstract}

Key words: smart house, renewable sources, wind power plant, photovoltaic power plant, control system

\section{INTRODUCTION}

The paper [5] published at the previous DAAAM conference presented the results of a newly built hybrid system powering the public lighting in the area of VSB - Technical University of Ostrava. By "hybrid" we understand the cooperation of a wind and photovoltaic power plant forming a source part of the system that jointly charges the accumulation equipment from which public lighting lamps are powered.

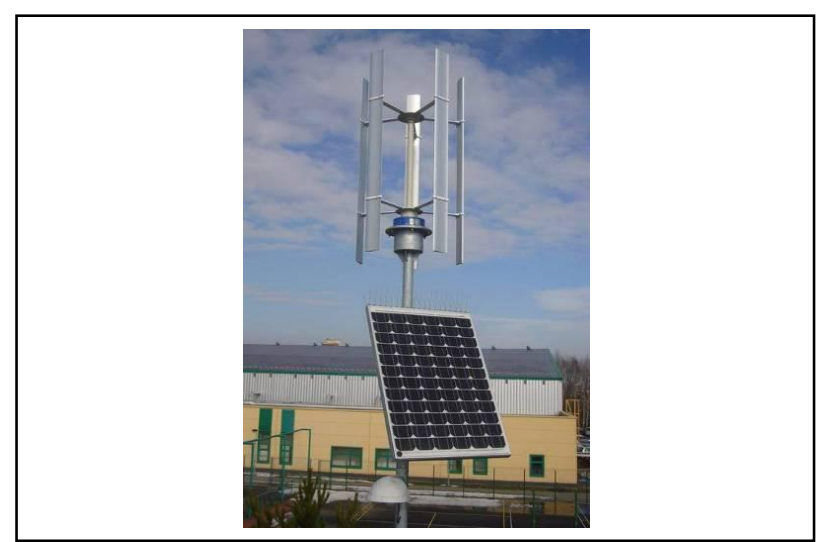

Fig.1. Photograph of a built hybrid system

The wind power plant is equipped with a synchronous generator with permanent magnets and the installed capacity of $300 \mathrm{Wp}$ and nominal voltage of $12 \mathrm{~V}$ working through an AC/DC converter to the $12 \mathrm{~V}$ bus bar. Also the photovoltaic power plant works within this DC voltage system equipped with monocrystalline cells with a total output of $200 \mathrm{Wp}$ and $17 \mathrm{~V}$ voltage. Subsequently an accumulation device with $\mathrm{NiCd}$ cells and total capacity of $340 \mathrm{~A} \cdot \mathrm{h}$ were designed according to $[1,2,3,7]$ and $12 \mathrm{~V}$ voltage is powered from the $12 \mathrm{~V}$ DC bus bar, which is rated for consumption powering with approx. $2 \times 3.3$ A take-off for a time interval of $52 \mathrm{~h}$. The 52 hour interval counts the take-off of approx. 6 days with total take-off of 8 hours (from 10 p.m. to 6 a.m.) for two public lighting lamps without charging input from both power plants.

At the moment, the said hybrid system has been in operation for more than half a year and the research implementation team that built the hybrid system has the unique results from testing the system power balance, electric power quality analysis and the analysis of the transient processes related to switching operations of individual power units.

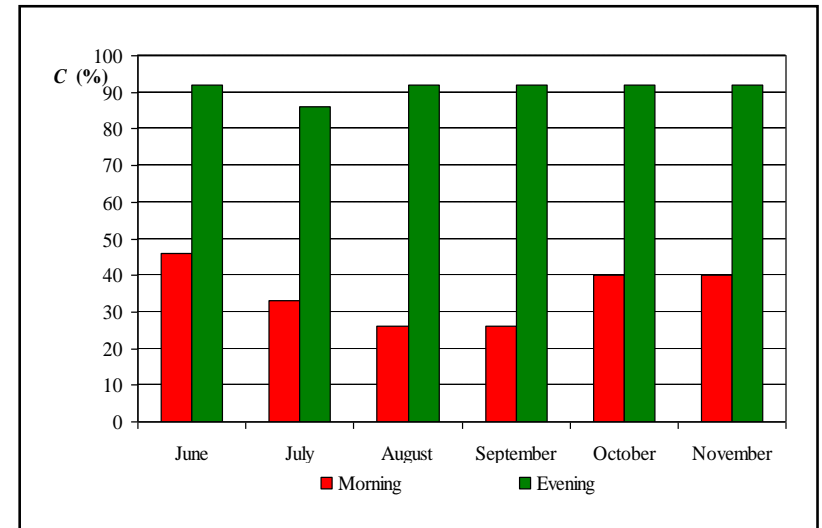

Fig.2. Battery Bank Capacity

Fig. 2 shows an example of the aforesaid analyses, namely an analysis of the accumulation system power balance. Red signifies the accumulation equipment condition in the morning, i.e. after completing a discharging cycle when powering public lighting lamps, green is the accumulation equipment condition after completing a charging cycle throughout a day. The figure shows the apparent self-sufficiency of the system for the entire monitoring system whereas the evaluation includes two yearly seasons with different weather conditions and thus the advantage of a hybrid source was fully applied here. It means that in summer months the accumulation equipment energy was subsidized largely from the photovoltaic power plant, while in autumn months the energy was subsidized from the wind power plant.

Then the results from hybrid source operation were used as a basis for the design and subsequent execution of the energy concept for a power self-sufficient house, a so-called Small Smart House, and thus the use of the hybrid system was moved from the output level of hundreds of Watts to the output level of units of $\mathrm{kW}$.

\section{ELECTRICAL POWER CONCEPT OF THE SMALL SMART SYSTEM}

As was mentioned in the last chapter, the concept of a small hybrid system was used as a basis for designing a new power concept of powering electric power consumption considering household consumption of a family house in an island system, i.e. a system that is power independent of an external energy system. The following basic conditions have been considered in developing the power concept:

the system will work in a so-called island system i.e. without having to connect it to any external energy system,

- $\quad$ only renewable ecological electric power sources will form a source part of the power concept system,

- the power obtained from renewable electric power sources is used for direct consumption powering and the energy surplus is accumulated in accumulation equipment, 
the system is operated as balanced electric power whereas controlling energy flows between individual components of the power concept will be executed using the SMART control system. Using the SMART system, the connection of individual family house consumption will be optimized based on the information on the predicted power value from the photovoltaic and wind power plants $[4,6]$, then also based on the defined connection priorities of individual loads, and based on a current value of accumulation equipment capacity.

Considering the above conditions the design of the power concept has been developed and a block diagram illustrating it is shown in Fig. 3.

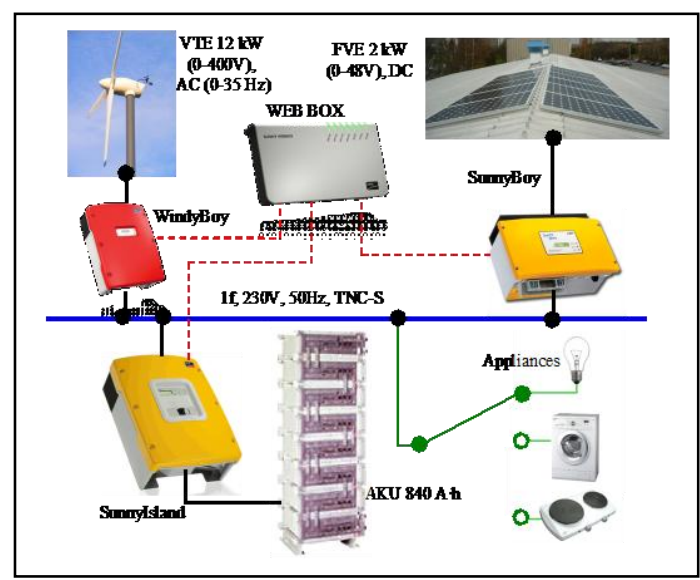

Fig.3.Power concept block diagram for the Small Smart House

The source part is formed by the wind power plant equipped with a synchronous generator with permanent magnets and the total installed capacity of $12 \mathrm{~kW}$, which is connected through a frequency converter with a recuperative unit to a 1 phase AC bus bar with $230 \mathrm{~V}$ level and $50 \mathrm{~Hz}$ frequency. As another renewable electric power source the photovoltaic power plant is used here with polycrystalline panels and the total installed output of $2 \mathrm{kWp}$, which contributes to the common 1 phase bus bar also through a frequency converter with optimizing supplied output. The electric power appliances are powered out of this bus bar and their individual connections are controlled according to the condition of the accumulation equipment, appliance connection priorities, nature of take-off and the predicted value of available power from the wind and photovoltaic power plants $[4,6]$. Connecting of the loads according to the requirements mentioned above is done using the Smart Control system, which also controls charging of the accumulation equipment with the total capacity of $840 \mathrm{~A} \cdot \mathrm{h}$ and voltage $48 \mathrm{~V}$ DC. This accumulation equipment with lead batteries balances the power and thus accumulates electric power in the case of surplus subsidy of electric power from the photovoltaic and wind power plant, and serves as a backup source for synchronizing power components in the case of direct powering of individual electric power appliances from the phase 1 bus bar. After designing the power concept it was executed whereby the wind and photovoltaic power plants were built up, individual power part components and the accumulation equipment were installed, and a concept representing the appliance composition of an ordinary household was created. The implementation also included building a weather station with the possibility of gauging basic quantities (wind velocity, wind direction, temperature, relative humidity, pressure, UV radiation) and the monitoring system, which measures a wide range of electric quantities. Using a combination of such systems it is possible to analyze in detail the efficiency of individual system components of the system as a whole, then to analyze the quality of electric power and analyze transient processes related to switch operations of individual system components.

\section{CONCLUSION}

The idea of the power concept created for the needs of powering a family house, a so-called Small Smart House, was implemented in the premises of the VŠB - Technical University of Ostrava in the Czech Republic. In this way, a unique and rare platform was created that can be used for Smart technology research with the possibility of a comprehensive analysis from the research of electric power prediction systems, through the analysis of electric power hybrid systems, to the analysis of electric power quality and the optimization of connecting individual appliances of a specified family-house household. This power concept was designed largely for powering the consumption of an ordinary household, however it can also be used for higher output levels and thus the implementation itself represents a physical model. Due to limited space the paper presents only the basic data.

\section{ACKNOWLEDGEMENTS}

This work was supported by the Ministry of Education, Youth and Sports of the Czech Republic (ENET No. CZ.1.05/2.1.00/03.0069) and project MSM 6198910007 and also project SP2011/130.

\section{REFERENCES}

Borowy, B.; Salameh, Z. (1996). Methodology for optimally sizing the combination of a battery bank and PV array in a wind/PV hybrid system. IEEE Transactions on Energy Conversion, Vol. 11, No. 2, p. 367-375, ISSN 0885-8969

Deshmukha M.; Deshmukh S. (2008) Modeling of hybrid renewable energy systems. Renewable and Sustainable Energy Reviews. Vol. 12, No.1, p. 235-249, ISSN 13640321

Kaabeche A, et al., (2011) Sizing optimization of gridindependent hybrid photovoltaic/wind power generation system, Energy, Vol. 36, No. 2, p. 1214-1222, ISSN 03605442

Misak, S.; Prokop, L.; Sikora, T.; Dasal, K.; Popławski, T.; Rusek, B. (2009). Wind Power Plant Production Prediction Using Various Models. Proceedings of 10th International Scientific Conference Electric Power Engineering 2009, Kouty nad Desnou, ISBN 978-80-248-1947-1, Rusek, S., Gono, R. (ed.). p. 152-157, Published by VSB-TU Ostrava, Ostrava

Kacor, P.; Misak, S. \& Prokop, L. (2010). Optimization and Redesign of Vertical Axis Wind Turbine for Generator of Independent Source of Energy, Annals of DAAAM for 2010 \& Proceedings of the 21st International DAAAM Symposium, 20-23rd October 2010, Zadar, Croatia, ISSN 1726-9679, ISBN 978-3-901509-73-5, Katalinic, B. (Ed.), pp. 1053-1054, Published by DAAAM International Vienna, Vienna

Prokop, L.; Misak, S.; Sikora, T.; Dąsal, K.; Popławski, T.; Rusek, B. (2009). Optimizing Electric Network Runnig with Wind Power Plant by using Produc-tion Prediction Mathematical Models. Rynek Energii, Vol. II, No.3, p.313318, ISSN 14255960

Zhou W.; Lou C.; Li Z.; Lu L.; Yang H. (2010) Current status of research on optimum sizing of stand-alone hybrid solarwind power generation systems. Applied Energy, Vol. 87, No. 2, p. 380-389 ISSN 0306-2619 